\title{
CORRELATION BETWEEN PSYCHOLOGICAL WELL-BEING AND INDICATORS OF OPTIMISM
}

\section{Summary}

\section{Introduction}

The research is based on the theory that a high level of optimism of an individual correlates with the indicators of subjective well-being.

\section{Aim of the Study}

To test two problem issues. The first one was: is there any statistically significant correlation between the indicators of psychological well-being and a high level of optimism? The second was: did the respondents with higher levels of income also have higher indicators of psychological well-being?

\section{Materials and Methods}

Ryff's Scales of Psychological Well-Being and Seligman's Attributional Style Questionnaire. The statistical method for the analysis of correlation was done with the help of Pearson's correlation coefficient.

\section{Results}

No statistically significant correlation was found between the indicators of the personality's positive sense of self and high level of optimisms, but it could be related to the low indicator of inner validity in Seligman's test (Cronbah's alpha: .3). As the test has not been standardised in Latvia, it could be the reasons for its low validity. Nevertheless, the analysis of the qualitative data obtained in the research showed that on the level of tendencies there is a correlation between the level of optimism and separate indicators of psychological and subjective well-being: personal development, sense of significance of one's life, relationships with other people.

To test the second problem issue of the research, Ryff's Scales of Psychological Well-Being was used, and the results were correlated to the level of monthly income stated by the respondents. The statistical method for finding a correlation between two attribute features was done by using the criterion of chi-square.

\section{Conclusions}

The results confirmed that there is a statistically significant correlation between the level of a respondent's income and his/her psychological well-being.

Keywords: psychological well-being, optimism, pessimism, satisfaction with the level of income.

\section{Introduction}

Latvian National Development Plan 2007-2013 (Index of Quality of Life of the Inhabitants of Latvia, 2006) states the beginning of implementation of a nationally significant aim: to increase the quality of life so that it would approach the average level in the European Union. Within the framework of the plan a range of interconnected aspects have been stated that need further research in order to state the quality of life and the factors constituting it: well-being, safety and long vital capacity. In total, there were 28 aspects stated that can be used to measure the improvement of 
one's quality of life; for example, awareness, education, creativity, employment, material welfare. Unfortunately, psychological well-being has not been stated as a separate aspect in the above plan, however, it is mentioned under the aspect of involvement stating that 'individual's psychological well-being is closely connected to involvement, subsidiarity in governing and decision making, involvement in NGO's, partnership between the public and private sector". Within the framework of the plans there was a research "Quality of Life in Latvia" carried out in 2005. The aim of the research was to gain a complex understanding of the problems and tendencies related to the quality of life. The research outlined the economic situation, employment, education, family, housing, health, social involvement, distribution of work and recreation time as the main criteria indicating the quality of life as seen by the inhabitants of Latvia. Most of them were subjective criteria: feeling of happiness, overall satisfaction of life and particular spheres of life. During the research, a poll of the inhabitants was done. The aim was to answer the question: How satisfied or dissatisfied are you with your life in general?. The answers gave a subjective picture of overall quality of life in Latvia. According to the research data, the inhabitants of Latvia had estimated their quality of life with 6.1 points in a 10 point system which means that in comparison with the year 2003 there is a positive improvement since in the previously mentioned year a similar poll was done and the result was 5.5 points. Today regular public opinion polls are done on the priority aspects of the quality of life and activities improving the quality of life. The polls have allowed identifying those aspects named by the inhabitants of Latvia that have been mentioned most often and which are seen as the criteria for increasing the quality of life by them: among the ones mentioned most often are material welfare, followed by employment and health, followed by social and physical safety, followed by education. It has to be stated that the above results correspond to Maslow's hierarchy of needs: the results of the polls in Latvia clearly mark a situation showing that people worry about the meeting of their fundamental needs. While the inhabitants do not earn enough money and feel unprotected, the intellectual values such as culture, growth and self-actualisation are not considered important aspects for increasing one's quality of life. Psychologists in Latvia have started work on devising a special training programme that could positively contribute to the growth of subjective well-being (such as psychological condition and mood) of the inhabitants after their groups being enrolled in it. Methods are being worked out and many people are already enrolling (especially in the biggest enterprises) in special training groups aiming at teaching how to achieve positive results and become more satisfied with life.

Even though estimating the psychological well-being and happiness is a relatively new field of research, there has been a number of research carried out on the topic stating which factors exactly influence the psychological well-being and how it can be increased. Thus, for instance, there has been a research in Germany aimed at stating whether a prestigious place of residence increases psychological well-being (Schkade \& Kahneman, 1998); in other researches the following questions were asked: is there a correlation between happiness and income (Diener, Oishi, 2002), or is there a connection between the level of optimism (Carver C. S., 2002) between the level of psychological well-being, or, when habits of expressing optimism and gratitude are changed, does it influence the level of positive feeling of well-being (Dickerhoof, Lyubomirsky \& Sheldon, 2007)?

\section{Aim of the Study}

To test the idea whether there is a connection between the indicators of subjective feeling of well-being and explicitness of optimism/pessimism both theoretically and practically as well as to test theoretically and practically whether there is a connection between the indicators of subjective well-being and the level of high income for a group of randomly selected adults in Latvia. 


\section{Materials and Methods}

In order to do a research on the connection between the psychological feeling of well-being and optimism/pessimism, two tests were used along with a demographic poll with one of the questions requiring the statement of the income level. The first test: Ryff"s Scales of Psychological Well-Being introduced by Caroll D. Ryff in 1989 (further in the text: Ryff) and the second: Dr. Martin Seligman's Attributional Style Questionnaire.

The full version of Ryff's test consists of 6 scales with the first scale being "Autonomy", the second scale - "Ability to manage complex environments to suit personal needs and values", the third scale - "Continued growth and development as a person", the fourth scale - "The establishment of quality ties to other", the fifth scale - "The pursuit of meaningful goals and a sense of purpose in life", the sixth scale - "Self-acceptance". The tests has not only been adapted in Latvia, but the students of RTTEMA have been granted a permission to use it. The test has been translated from English: two translators were translating it into Latvian, and the translation was done by Beijere and Blumberga. The validity indicators (Cronbah's alpha) for the test of psychological well-being are 0,887 .

The second test Attributional Style Questionnaire by Martin Seligman consists if 48 questions aiming at identifying individual's optimism or pessimism in his or her attitude towards the events in his/her life. 24 questions have been included to assess the negative events, and they form a separate Scale B whereas other 24 questions have been included to assess the positive events forming a separate Scale G. Every question has 2 response choices. One statement matches an optimistic style of assessment, the other one - pessimistic. Optimism or pessimism is assess through the results obtained from the total result of Scale $G$ with the result from Scale B subtracted from it thus indicating whether the individual is an optimistic, pessimistic or neutral.

To establish the level of income of the respondents as well as their attitude towards the level of income two questions were added: is the respondent satisfied or not with his/her income and what is the income of the respondent.

Idea of the connection between the subjective feeling of well-being and level of income

When researching the differences between welfare and psychological well-being in various nations, researchers (Cassidy, 2002, Miller, 2002) came to a deeper understanding about the connection between the level of income and psychological well-being. Some of them claimed that wealth encourages the feeling of psychological well-being only among the poorest nations when the fundamental needs are at stake or have not been met at all. It was discovered (Diener, 1995) that even when the fundamental needs are controlled, the income create a significant influence on the national psychological well-being therefore people in wealthier nations have a tendency to be happier. It is possible because they not only possess more material values but also because wealthier nations have a higher level of human rights, longer average life-span and greater equality.

Figure 1. Money and happiness according to

To see whether there is a positive correlation between happiness and money a broad research was done (Diener, Oishi, 2002) with 7167 students from 41 countries taking part in it. The respondents valuing love higher than money also showed a greater satisfaction with life than those focussing on income (see Figure 1).

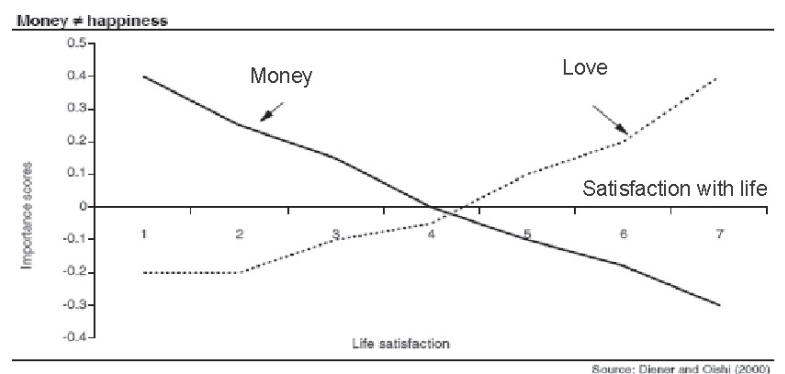


Researchers of RTTEMA Guna Svence and Santa Golde were also interested in testing the above hypothesis therefore a research aiming at finding out whether there is a connection between the level of income and subjective feeling of well-being was done.

The second question in the research was: is there a connection between the indicators of psychological feeling of well-being and explicitness of optimism/pessimism.

Theoretical grounds of the connection between the feeling of psychological well-being and the level of optimism

Within the framework of this article, Table 1 has been created summarising the information acquired while doing meta-analysis of similar research papers. In modern psychology the indicators of the feeling of subjective well-being are connected with the indicators of optimism, expression of gratitude, growth of the feeling of the quality of life and improvement of health, formulation of aims, depression, and motivation for achievement. As two of the keywords of the article are optimism and subjective feeling of well-being, through the meta-analysis of the newest research the authors of the article became convinced that the theme is topical and valid in modern psychology.

Table 1. Theoretical grounds of the connection between the feeling of psychological well-being and the level of optimism in similar research papers.

\begin{tabular}{|c|c|c|c|}
\hline Author & Hypothesis/Idea/Topic & Outcome of the research & Year \\
\hline $\begin{array}{l}\text { Dickerhoof, } \\
\text { Lyubomirsky \& } \\
\text { Sheldon }\end{array}$ & $\begin{array}{l}\text { Expression of optimism } \\
\text { and gratitude increases the } \\
\text { psychological well-being. }\end{array}$ & $\begin{array}{l}\text { Regular optimistic and grateful thinking increases the } \\
\text { satisfaction with weekly experience of life which, in } \\
\text { turn, increases the psychological well-being. }\end{array}$ & 2007 \\
\hline Burant C. J. & $\begin{array}{l}\text { The level of optimism and } \\
\text { pessimism influences the } \\
\text { recovery from chronic illnesses. }\end{array}$ & $\begin{array}{l}\text { Pessimism initially impacts the level of physical } \\
\text { functioning and depression. As a result a high feeling of } \\
\text { psychological well-being cannot be expected. }\end{array}$ & 2006 \\
\hline Turkum A. S. & $\begin{array}{l}\text { Optimism, submissive } \\
\text { behaviour, the number of social } \\
\text { contacts and demographical } \\
\text { variables set the psychological } \\
\text { well-being. }\end{array}$ & $\begin{array}{l}\text { Psychological well-being is set by optimism, } \\
\text { submission, marital status and occupation. } \\
\text { The number of social contacts, gender and level of } \\
\text { education insignificantly correlate with psychological } \\
\text { well-being. }\end{array}$ & 2005 \\
\hline $\begin{array}{l}\text { Wrosch Carsten \& } \\
\text { Scheier Michael F. }\end{array}$ & $\begin{array}{l}\text { Optimism and setting of aims } \\
\text { influence the quality of life. }\end{array}$ & $\begin{array}{l}\text { Both optimism and creation of aims are important for } \\
\text { making an order in personal aims and growth. The } \\
\text { result is a high quality of life. }\end{array}$ & 2003 \\
\hline Cassidy T. & $\begin{array}{l}\text { Motivation for achievements and } \\
\text { optimism are predisposing to } \\
\text { both psychological well-being as } \\
\text { well as self-assessment of one's } \\
\text { health. }\end{array}$ & $\begin{array}{l}\text { The hypothesis was confirmed in a research done in } \\
\text { Great Britain lasting for four years. }\end{array}$ & 2000 \\
\hline Shifren \& Hooker & $\begin{array}{l}\text { Optimisms positively influences } \\
\text { the feeling of psychological } \\
\text { well-being for the spouses } \\
\text { of people suffering from } \\
\text { Alzheimer's disease. }\end{array}$ & $\begin{array}{l}\text { Optimism correlates with a lower level of depression } \\
\text { and a higher level of psychological well-being. }\end{array}$ & 1995 \\
\hline Carver et. al. & $\begin{array}{l}\text { Connection between optimism } \\
\text { and adaptation to the therapy of } \\
\text { breast cancer in the initial stage. }\end{array}$ & $\begin{array}{l}\text { Optimism not only decreases suffering but also } \\
\text { increases joy of living in a course of one year after the } \\
\text { operation. }\end{array}$ & 1993 \\
\hline Given et. al. & $\begin{array}{l}\text { Optimisms positively influences } \\
\text { the feeling of psychological } \\
\text { well-being for the people taking } \\
\text { care of patients. }\end{array}$ & $\begin{array}{l}\text { The level of optimism of the people taking care of the } \\
\text { ill correlates with fewer symptoms of depression. One } \\
\text { could also observe less impact on the physical health } \\
\text { and everyday activities. }\end{array}$ & 1993 \\
\hline Scheier et al. & $\begin{array}{l}\text { Optimistic men recovering from } \\
\text { coronary artery operations have } \\
\text { a higher quality of life than those } \\
\text { being pessimistic. }\end{array}$ & $\begin{array}{l}\text { Assessments done after one week, } 6 \text { months, } 5 \text { years } \\
\text { showed that optimists have a greater psychological } \\
\text { well-being and quality of life. }\end{array}$ & 1989 \\
\hline
\end{tabular}




\section{Results}

The results on the first question of the research: is there any statistically significant correlation between the indicators of psychological well-being and a high level of optimism?

The research question: "Is there any statistically significant correlation between psychological well-being and optimism?" did not prove to be true, however, if choosing a different test for determining optimism this correlation might show itself true. There is a correlation on the level of tendencies between the explicitness of the level of optimism/pessimism and scales "Continued growth and development as a person", "The pursuit of meaningful goals and a sense of purpose in life" and "The establishment of quality ties to other". This research shows that respondents with an optimistic set of mind have more excplicit ability to fit in the society as well as they have a more positive attitude towards themselves (see Table 2).

Table 2. The correlation coefficients between the following scales of psychological well-being "Autonomy", "Ability to manage complex environments to suit personal needs and values", "Continued growth and development as a person", "The establishment of quality ties to other",

"The pursuit of meaningful goals and a sense of purpose in life", "Self-acceptance" and the level of feeling optimism/pessimism.

\begin{tabular}{|c|c|c|c|c|c|c|c|c|}
\hline & & Optimism & Acceptance & Autonomy & Society & Growth & Relationships & $\begin{array}{c}\text { Purpose } \\
\text { of life }\end{array}$ \\
\hline \multirow[t]{3}{*}{$\begin{array}{l}\text { Optimism } \\
\text { /pessimism }\end{array}$} & \begin{tabular}{|l|} 
Pearson \\
Correlation
\end{tabular} & 1 & -.002 & .164 & .249 & .268 & .228 & .271 \\
\hline & Sig.: (2-tailed) & & .992 & .305 & .117 & .090 & .151 & .087 \\
\hline & $\mathrm{N}$ & 41 & 41 & 41 & 41 & 41 & 41 & 41 \\
\hline \multirow[t]{3}{*}{$\begin{array}{l}\text { Self- } \\
\text { acceptance }\end{array}$} & $\begin{array}{l}\text { Pearson } \\
\text { Correlation }\end{array}$ & -.002 & 1 & $.370(*)$ & $.551(* *)$ & .022 & $.478(* *)$ & $.516(* *)$ \\
\hline & Sig.: (2-tailed) & .992 & & .017 & .000 & .890 & .002 & .001 \\
\hline & $\mathrm{N}$ & 41 & 41 & 41 & 41 & 41 & 41 & 41 \\
\hline \multirow[t]{3}{*}{ Autonomy } & $\begin{array}{l}\text { Pearson } \\
\text { Correlation }\end{array}$ & .164 & $.370(*)$ & 1 & $.320(*)$ & .246 & .088 & $.420(* *)$ \\
\hline & Sig.: (2-tailed) & .305 & .017 & & .041 & .121 & .583 & .006 \\
\hline & $\mathrm{N}$ & 41 & 41 & 41 & 41 & 41 & 41 & 41 \\
\hline \multirow[t]{3}{*}{$\begin{array}{l}\text { Ability to fit } \\
\text { into the society } \\
\end{array}$} & $\begin{array}{l}\text { Pearson } \\
\text { Correlation }\end{array}$ & .249 & $.551(* *)$ & $.320(*)$ & 1 & .038 & $.449(* *)$ & $.506(* *)$ \\
\hline & Sig.: (2-tailed) & .117 & .000 & .041 & & .815 & .003 & .001 \\
\hline & $\mathrm{N}$ & 41 & 41 & 41 & 41 & 41 & 41 & 41 \\
\hline \multirow[t]{3}{*}{$\begin{array}{l}\text { Personal } \\
\text { growth }\end{array}$} & $\begin{array}{l}\text { Pearson } \\
\text { Correlation }\end{array}$ & .268 & .022 & .246 & .038 & 1 & .176 & $.471(* *)$ \\
\hline & Sig.: (2-tailed) & .090 & .890 & .121 & .815 & & .270 & .002 \\
\hline & $\mathrm{N}$ & 41 & 41 & 41 & 41 & 41 & 41 & 41 \\
\hline \multirow[t]{3}{*}{$\begin{array}{l}\text { Positive } \\
\text { relationships }\end{array}$} & $\begin{array}{l}\text { Pearson } \\
\text { Correlation }\end{array}$ & .228 & $.478(* *)$ & .088 & $.449(* *)$ & .176 & 1 & $.332(*)$ \\
\hline & Sig.: (2-tailed) & .151 & .002 & .583 & .003 & .270 & & .034 \\
\hline & $\mathrm{N}$ & 41 & 41 & 41 & 41 & 41 & 41 & 41 \\
\hline \multirow[t]{3}{*}{ Purpose of life } & \begin{tabular}{|l|} 
Pearson \\
Correlation
\end{tabular} & .271 & $.516(* *)$ & $.420(* *)$ & $.506(* *)$ & $.471(* *)$ & $.332(*)$ & 1 \\
\hline & Sig.: (2-tailed) & .087 & .001 & .006 & .001 & .002 & .034 & \\
\hline & $\mathrm{N}$ & 41 & 41 & 41 & 41 & 41 & 41 & 41 \\
\hline
\end{tabular}

* Correlation is significant at the 0.05 level (2-tailed).

** Correlation is significant at the 0.01 level (2-tailed). 
Even though the research done by other scientists show that the indicators of optimism/pessimism correlate with the feeling of subjective well-being, in this research the correlation shows itself only on the level of tendencies. How shall it be explained? Possibly, one of the reasons is the specifics in processing the mathematically statistical data and results which in the first place state: the bigger the sample, the more valid the results are. Secondly, the tool for measuring the explicitness of optimism/pessimism - Seligman's poll - and the indicator of the inner coordination was only .4 (when it should be at least .7). This shows that the chosen methodology might not be suitable for the particular cultural environment. It could also be influenced by a small sample: should it be larger, the indicators might change. This research shows that other similar researchers in Latvia need to be done with larger samples.

The second research question was: did the respondents with higher levels of income also have higher indicators of psychological well-being?

The second research question: "Did higher levels of income also mean a higher level of psychological well-being?" has shown to be true.

The result partially meets the viewpoint of the authors analysed in the theoretical part of the paper (Wilson, 1967): higher level of income does not mean a higher level of psychological well-being, that is, money does not guarantee happiness. At the same time it has been proved that the countries with an unstable economic and political situation as well as in the countries without continuing prosperity and democracy the level of income significantly correlates with the level of psychological well-being. The results correspond to the viewpoint of the authors of the article: in a favourable cultural and historical setting level of income is not of a prime significance, however, when one often has to think how to meet his/her and the family's fundamental needs, the material welfare significantly influences psychological well-being.

In order to establish whether the level of psychological wellbeing increases with an increase of a greater level of income, a nonparametric statistical method - the criterion of chi-square $\left(\chi^{2}\right)$ - was used showing the connection between to attribute features.

Initially, the data about income were put into a table and grouped into six groups. Then a table with the number of variants of the responses in the test of the psychological well-being and the income groups was created. To obtain $\chi^{2}$, the estimation of $\chi^{2}$ was done for the level of respondents' income and the total results of the test of the psychological well-being. The result acquired $\chi_{\text {est }}^{2}=760.50 \cdot \chi_{\text {crit }}^{2}$ $(\mathrm{v}=165, \alpha=0,05) \approx 197.14$. As $\chi_{\text {est }}^{2}>\chi_{\text {crit }}^{2}, 760,5>197.14$, its means that a significant connection between the respondent's level of income and psychological well-being is established (see Table 3).
Table 3. Calculations of chi-square for the level of the respondents' income and the total results of the psychological well-being test.

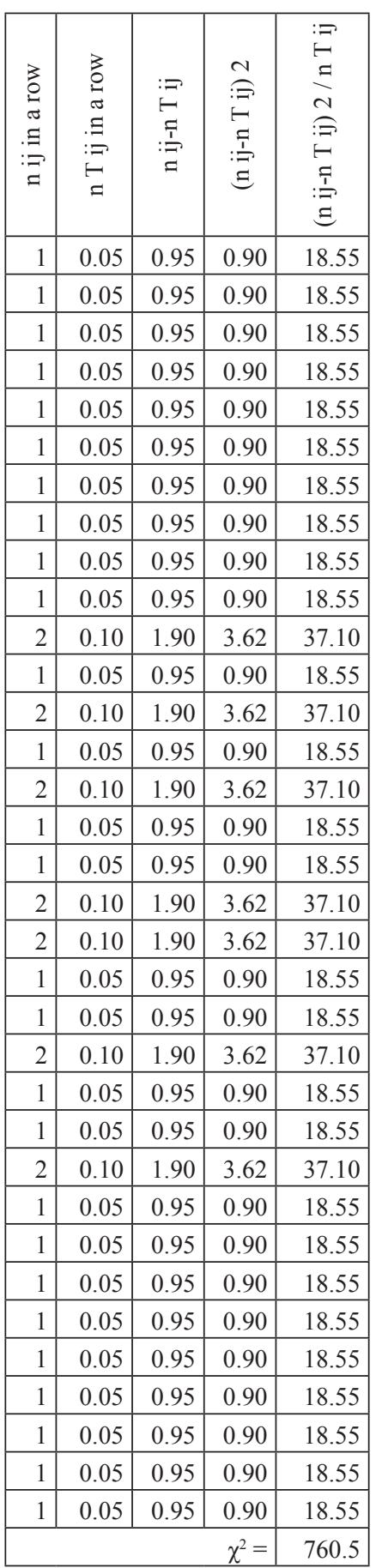




\section{Conclusions}

1. There is a connection on the level of tendencies between the explicitness of optimism and the components of psychological well-being: personal growth, purpose of life and ability to fit into the society.

2. There is a statistically significant correlation between the level of a respondent's income and his/her psychological well-being.

\section{REFERENCES}

1. Burant C. (2006) Optimism/pessimism as a Mediator of Social Structural Disparities Effects on Physical Health and Psychological Well-Being: A Longitudinal Study of Hospitalized Elders - Case Western Reserve University, p. 1-305. www.psycinfo.com (10.11.2007.)

2. Carver C. S. (2002) Cognitive Approaches. Optimism // Handbook of Positive Psychology / Ed. by Snyder C. R., Lopez S. J. Oxford University Press, p. 231-243. www.psycinfo.com (12.11.2007.)

3. Cassidy T. (2002) Social Background, Achievement Motivation, Optimism and Health: a longitudinal Study // Counselling Psychology Quarterly, Vol. 13 Issue 4, p. 399-413. www.psycinfo.com (23.10.2007.)

4. Cummins R. A. (2000) Personal Income and Subjective well-being // Journal of Happiness Studies. Kluwer Academic Publishers, p. 33-58. www.psycinfo.com (09.09.2007)

5. Diener E., Lucas R. E., Oishi S. (2002) Subjective Well-Being. The Science of Happiness and Satisfaction // Handbook of Positive Psychology / Ed. by Snyder C. R., Lopez S. J. Oxford University Press, p. 63-73. www.psycinfo.com (10.11.2007.)

6. Latvijas iedzīvotāju dzīves kvalitātes indekss (2006) Stratēgiskās analīzes komisijas darba grupas atskaite / Koord. Karnīte E. Rīga.

7. Miller M. C. (2002) The Benefits of Positive Psychology // Harvard Mental Health Letter, Vol. 18 Issue 7, p. 1-6. www.psycinfo.com (10.11.2007.)

8. Montier J. (2004) Global Equity Strategy. If it makes you happy. Dresdner Kleinwort Wasserstein Securities Limited, p. 1-8. www.psycinfo.com (10.11.2007.)

9. Ryff C. D. (1989). Happiness Is Everything, or Is It? Explorations on the Meaning of Psychological Well-Being // Journal of Personality and Social Personality, 57, p. 1069-1081 p. www.psycinfo.com (15.08.2007.)

10. Turkum A. S. (2005) Do Optimism, Social Network Richness and Submissive Behaviors Predict wellbeing? Social Behavior and Personality. 33 (6), p. 619.-628. www.psycinfo.com (15.08.2007.)

11. Wrosch C., Scheier M. F. (2003) Personality and Quality of Life: The Importance of Optimism and Goal Adjustment. Quality of Life Research 12 (Suppl. 1). Kluwer Academic Publishers, p. 59-72. www.psycinfo.com (17.08.2007.)

Lecturer Dr. psych. Guna Svence

Riga Teacher Training and Educational Management Academy

Address: Imantas 7. līnija 1, Rīga, LV-1083, Latvija

Phone: +37167808010

E-mail: gunasvence@,rpiva.lv

Psychology Master Level Student Bc. psych. Santa Golde

Riga Teacher Training and Educational Management Academy

Address: Imantas 7. līnija 1, Rīga, LV1083, Latvija

Phone: +371 67808010

E-mail: sgolde@apollo.lv 